\title{
Synthesis of pyrrolo[1,2-a]quinolines by formal 1,3-dipolar cycloaddition reactions of quinolinium salts
}

\author{
Anthony Choi, Rebecca M. Morley and lain Coldham ${ }^{*} \S$
}

\author{
Full Research Paper \\ Address: \\ Department of Chemistry, University of Sheffield, Brook Hill, Sheffield, \\ S3 7HF, UK \\ Email: \\ lain Coldham* - i.coldham@sheffield.ac.uk \\ * Corresponding author \\ § Fax: +44(0)114 2229346 \\ Keywords: \\ azomethine ylide; cycloaddition; heterocycle; pyrrolidine; \\ stereoselective
}

Beilstein J. Org. Chem. 2019, 15, 1480-1484.

doi:10.3762/bjoc. 15.149

Received: 08 April 2019

Accepted: 27 June 2019

Published: 03 July 2019

Associate Editor: J. Aubé

(c) 2019 Choi et al.; licensee Beilstein-Institut.

License and terms: see end of document.

\begin{abstract}
Quinolinium salts, $\mathrm{Q}^{+}-\mathrm{CH}_{2}-\mathrm{CO}_{2} \mathrm{Me} \mathrm{Br}^{-}$and $\mathrm{Q}^{+}-\mathrm{CH}_{2}-\mathrm{CONMe}_{2} \mathrm{Br}^{-}$(where $\mathrm{Q}=$ quinoline), were prepared from quinolines. Deprotonation of these salts with triethylamine promoted the reaction of the resulting quinolinium ylides (formally azomethine ylides) with electron-poor alkenes by conjugate addition followed by cyclization or by [3 +2$]$ dipolar cycloaddition. The pyrroloquinoline products were formed as single regio- and stereoisomers. These could be converted to other derivatives by Suzuki-Miyaura coupling, reduction or oxidation reactions.
\end{abstract}

\section{Introduction}

Cycloaddition reactions of azomethine ylides are an important class of pericyclic reactions that give rise to pyrrolidine rings, prevalent in a large number of natural products and bioactive compounds. Many methods have been used to prepare azomethine ylides that undergo cycloaddition with $\pi$-systems, especially electron-poor alkenes to give pyrrolidine products [1-4]. Azomethine ylides can be classed either as stabilised or nonstabilised, depending on the presence or absence of an electronwithdrawing substituent such as a carbonyl group. The most common method for their preparation is by condensation of a secondary amine with an aldehyde to give an iminium ion that loses a proton to give the ylide, or by condensation of a primary amine with an aldehyde to give an imine followed by prototropy or deprotonation to give $N$-metalated azomethine ylides (see, for example, [5-18]). An alternative method is to prepare a salt of a heterocycle, typically by $\mathrm{N}$-alkylation of a pyridine [19-27], isoquinoline [26-32], or related structures [33$35]$, followed by deprotonation. Such ylides are formally azomethine structures assuming reactivity of the aromatic ring as an iminium ion, although the reaction with electron-poor alkenes occurs through a stepwise conjugate addition-cyclization process [23]. We were interested in the related quinolinium ylides that, on (formal) cycloaddition would provide pyrrolo[1,2- $a]$ quinolines as products. These are tricyclic compounds consisting of a pyrrole ring fused with a quinoline. Pyrroloquinolines have been found to show antibacterial and 
antifungal activity, to be ligands for the $\mathrm{NK}_{1}$ receptor, and to be effective against the Hif hypoxia pathway in cancer cell lines [36-38]. Almost all of the examples of dipolar cycloaddition reactions involving quinolinium salts that have been reported in the literature involve ketones as electron-withdrawing groups to stabilise the intermediate ylide [39-49]; for example, the ketone $\mathbf{1}$ is known to undergo reaction with alkenes $\mathbf{2}(\mathrm{Z}=$ electronwithdrawing group) to give the tricyclic products $\mathbf{3}$ (Scheme 1) $[41,49]$. Similar examples with phenanthridinium and related ylides make use of ketones to stabilise the ylide [50-54]. The only exception (as far as we are aware) to the use of quinolinium ylides with ketones as stabilising groups are isolated reports with a carboxylic acid derivative, particular an ethyl ester group [55-59]. Here we describe a wider scope that extends the examples to alternative carbonyl derivatives and alternative alkenes, hence providing novel pyrroloquinoline compounds.<smiles>CCN(CC)CC=C[C+]Br</smiles>

1 $\mathrm{Z}=\mathrm{COPh}, \mathrm{CN}, \mathrm{COMe}, \mathrm{NO}_{2}$

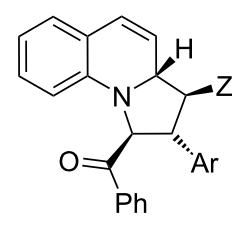

3
Scheme 1: Reaction of ketone 1 with electron-deficient alkenes 2.

\section{Results and Discussion}

To test the feasibility of the reaction of quinolinium salts bearing electron-withdrawing groups other than ketones, we prepared ester 4 [55] and amide 5 by alkylation of quinoline. Arylidenemalononitriles such as $\mathbf{6 a}$ are known to undergo related chemistry [41], so we heated this compound with the quinolinium salts in the presence of triethylamine and were pleased to obtain good yields of the adducts $\mathbf{7 a - c}$ and $\mathbf{8 a}, \mathbf{b}$ (Scheme 2).

In each case, the products $7 \mathbf{a}-\mathbf{c}$ and $\mathbf{8 a}, \mathbf{b}$ were formed as a single regioisomer and stereoisomer. The selectivity in favour of the isomer drawn in Scheme 2 was verified by single crystal $\mathrm{X}$-ray analysis of the adduct 7c (Figure 1). The other isomers had similar coupling constants between adjacent protons and were assumed to have the same relative configuration.

A dipolarophile that has not been reported for reaction with quinolinium salts is $N$-methylmaleimide. We therefore tested the ability of this unsaturated compound to undergo reaction with the ylides derived from the salts $\mathbf{4}$ and $\mathbf{5}$. In both cases, very good yields of the tetracyclic adducts $\mathbf{9}$ and $\mathbf{1 0}$ were obtained after heating for only $1 \mathrm{~h}$ (Scheme 3 ). The relative

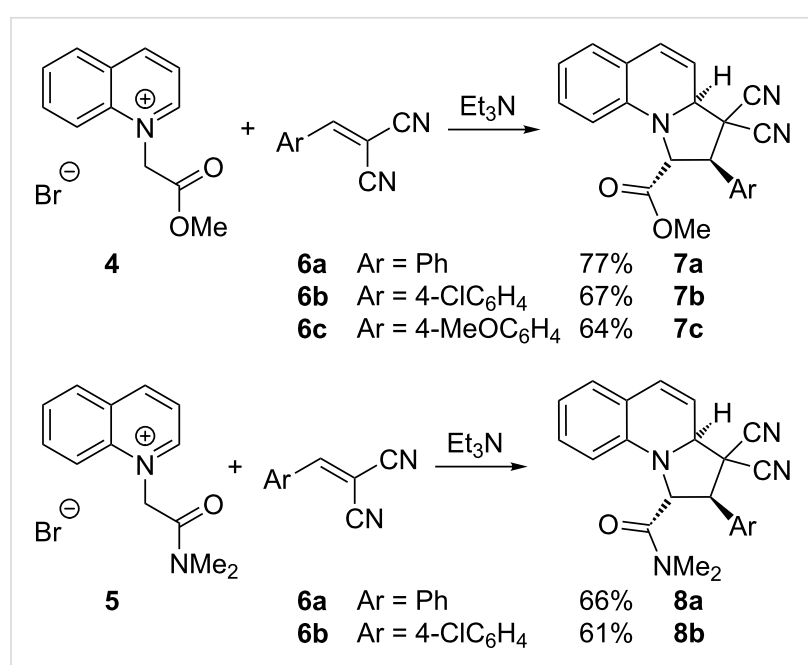

Scheme 2: Reactions of ester $\mathbf{4}$ and amide 5 with electron-deficient alkenes 6 .

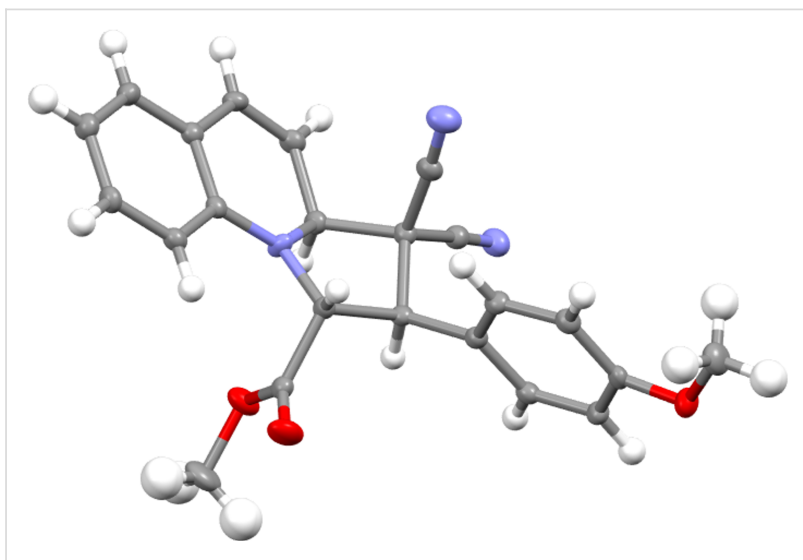

Figure 1: Single crystal X-ray structure for 7c.

stereochemistry of the adduct 9 was determined by single crystal X-ray analysis (Figure 2).

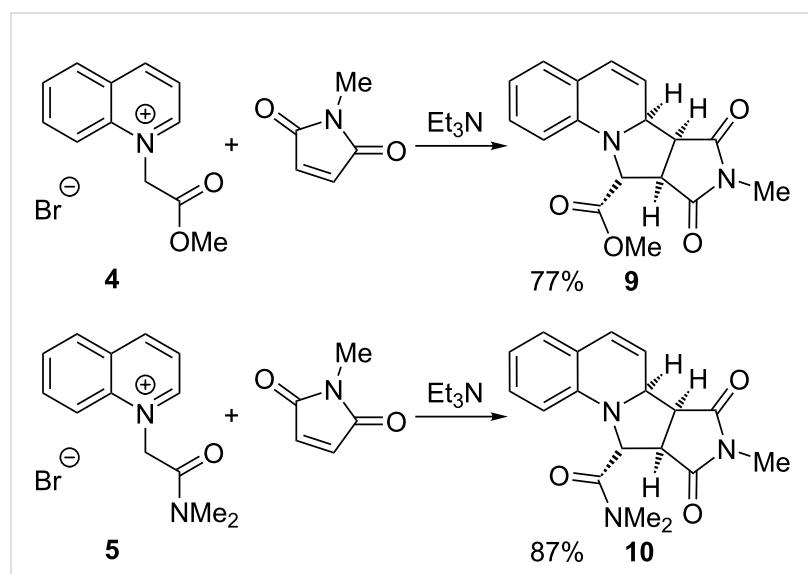

Scheme 3: Reactions of ester $\mathbf{4}$ and amide $\mathbf{5}$ with $\mathrm{N}$-methylmaleimide. 


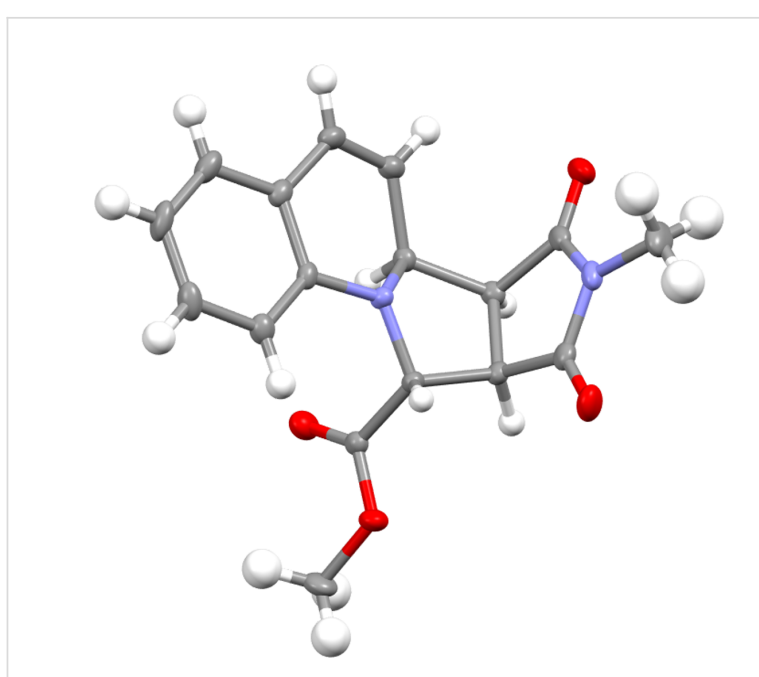

Figure 2: Single crystal X-ray structure for 9.

To explore the diversity of products that could be obtained from these adducts, we carried out a reduction of the alkene in compounds $\mathbf{9}$ and $\mathbf{1 0}$ by using hydrogen and palladium on charcoal (Scheme 4). This provides the tetrahydroquinoline adducts $\mathbf{1 1}$ and 12. Additionally, and in contrast, oxidation of the adduct $\mathbf{1 0}$ was performed using the oxidant 2,3-dichloro-5,6-dicyanoquinone (DDQ) to give the fully unsaturated product $\mathbf{1 3}$.

To expand the range of products and explore the scope of the reaction further, we prepared the salts $\mathbf{1 4 a}$ and $\mathbf{1 4 b}$ (from 6-chloroquinoline and 6-bromoquinoline) and these were heated with $N$-methylmaleimide in the presence of triethylamine in methanol to give the desired adducts $\mathbf{1 5 a}$ and $\mathbf{1 5} \mathbf{b}$ as single stereoisomers (Scheme 5). The stereochemistry of product $\mathbf{1 5 a}$ was confirmed by single crystal X-ray analysis (see Supporting Information File 1) and matches the relative configuration of the adducts 9 and 10. The bromide $\mathbf{1 5 b}$ was coupled with phenylboronic acid using palladium catalysis to give derivative 16 (the chloride 15a was inert under these conditions). The ability to prepare halogenated derivatives and to undergo palladium coupling demonstrates further versatility of these types of products.

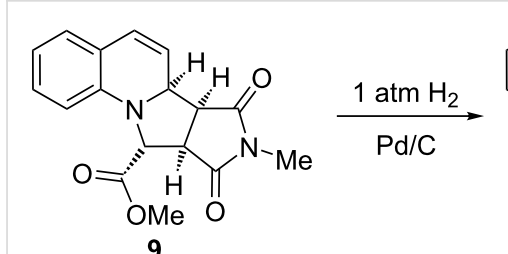

9<smiles>COC(=O)[C@H]1[C@@H]2C(=O)N(C)C(=O)[C@@H]2[C@H]2CCc3ccccc3N21</smiles>

$85 \% \quad 11$<smiles>CN1C(=O)[C@@H]2[C@H](C(=O)N1C)[C@@]1(C)C=Cc3ccccc3N21</smiles>

10<smiles>CNC(=O)[C@H]1[C@@H]2C(=O)N(C)C(=O)[C@@H]2[C@@H]2CCc3ccccc3N21</smiles>

$73 \% \quad 12$<smiles>CNC(=O)[C@@H]1[C@@H]2C(=O)N(C)C(=O)[C@@H]2[C@H]2C=Cc3ccccc3N12</smiles>

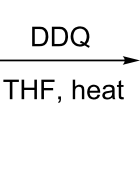<smiles>CNC(=O)c1c2c(c3ccc4ccccc4n13)C(=O)N(C)C2=O</smiles>

$57 \% \quad 13$

Scheme 4: Reduction and oxidation of adducts 9 and 10.

\section{Conclusion}

In conclusion, we have found that carboxylic ester and amidestabilised anions derived from quinolinium salts react with arylidenemalononitriles and $\mathrm{N}$-methylmaleimide to give adducts in good yields and with very high stereoselectivity (single isomer products were isolated). The adducts could be reduced, oxidised, or could undergo Suzuki-Miyaura coupling to give different substituted dihydro- and tetrahydroquinoline derivatives.

\section{Supporting Information}

\section{Supporting Information File 1}

Experimental procedures, spectroscopic and X-ray data (CCDC 1907018-1907020 for compounds 7c, 9 and 15a) and copies of NMR spectra.

[https://www.beilstein-journals.org/bjoc/content/ supplementary/1860-5397-15-149-S1.pdf]<smiles>[X]c1ccc2c(ccc[n+]2CC(=O)NCCC)c1</smiles>

14a $X=\mathrm{Cl}$

14b $\mathrm{X}=\mathrm{Br}$<smiles>[X]c1ccc2c(c1)C=CC1(C2)[C@H]2C(=O)N(C)C(=O)[C@H]2[C@H]1C(N)=O</smiles>

\section{using 15b} $\mathrm{PhB}(\mathrm{OH})_{2}$

$\mathrm{Pd}\left(\mathrm{PPh}_{3}\right)_{4}$ $\mathrm{Na}_{2} \mathrm{CO}_{3}, \mathrm{H}_{2} \mathrm{O}$ $\mathrm{EtOH}, \mathrm{PhMe}$ $67 \%$<smiles>CNC(=O)[C@H]1[C@H]2C(=O)N(C)C(=O)[C@H]2[C@@]2(C)C=Cc3cc(-c4ccccc4)ccc3N12</smiles>

$61 \% \quad 16$ 


\section{Acknowledgements}

We thank the EPSRC and the University of Sheffield for funding. Craig Robertson (University of Sheffield) is thanked for single crystal X-ray studies.

\section{ORCID ${ }^{\circledR}$ iDs}

lain Coldham - https://orcid.org/0000-0003-4602-6292

\section{References}

1. Li, J.; Ye, Y.; Zhang, Y. Org. Chem. Front. 2018, 5, 864-892. doi:10.1039/c7qo01077j

2. Meyer, A. G.; Ryan, J. H. Molecules 2016, 21, 935. doi:10.3390/molecules21080935

3. Moyano, A.; Rios, R. Chem. Rev. 2011, 111, 4703-4832. doi:10.1021/cr100348t

4. Coldham, I.; Hufton, R. Chem. Rev. 2005, 105, 2765-2810. doi:10.1021/cr040004c

5. Xiong, Y.; Du, Z.; Chen, H.; Yang, Z.; Tan, Q.; Zhang, C.; Zhu, L.; Lan, Y.; Zhang, M. J. Am. Chem. Soc. 2019, 141, 961-971. doi:10.1021/jacs.8b10939

6. Filatov, A. S.; Knyazev, N. A.; Shmakov, S. V.; Bogdanov, A. A.; Ryazantsev, M. N.; Shtyrov, A. A.; Starova, G. L.; Molchanov, A. P.; Larina, A. G.; Boitsov, V. M.; Stepakov, A. V. Synthesis 2019, 51, 713-729. doi:10.1055/s-0037-1611059

7. Jia, Z.-J.; Shan, G.; Daniliuc, C. G.; Antonchick, A. P.; Waldmann, H. Angew. Chem., Int. Ed. 2018, 57, 14493-14497. doi:10.1002/anie.201712882

8. Feng, B.; Lu, L.-Q.; Chen, J.-R.; Feng, G.; He, B.-Q.; Lu, B.; Xiao, W.-J. Angew. Chem., Int. Ed. 2018, 57, 5888-5892. doi:10.1002/anie.201802492

9. Xu, S.; Zhang, Z.-M.; Xu, B.; Liu, B.; Liu, Y.; Zhang, J. J. Am. Chem. Soc. 2018, 140, 2272-2283. doi:10.1021/jacs.7b12137

10. Williams, B. M.; Trauner, D. J. Org. Chem. 2018, 83, 3061-3068. doi:10.1021/acs.joc.8b00192

11. Zhang, Q.; Zhang, Z.; Huang, Z.; Zhang, C.; Xi, S.; Zhang, M. Angew. Chem., Int. Ed. 2018, 57, 937-941. doi:10.1002/anie.201711414

12. Otero-Fraga, J.; Suárez-Pantiga, S.; Montesinos-Magraner, M.; Rhein, D.; Mendoza, A. Angew. Chem., Int. Ed. 2017, 56, 12962-12966. doi:10.1002/anie.201706682

13. Erguven, H.; Leitch, D. C.; Keyzer, E. N.; Arndtsen, B. A. Angew. Chem., Int. Ed. 2017, 56, 6078-6082. doi:10.1002/anie.201609726

14. Hauduc, C.; Bélanger, G. J. Org. Chem. 2017, 82, 4703-4712. doi:10.1021/acs.joc.7b00345

15. Boissarie, P.; Bélanger, G. Org. Lett. 2017, 19, 3739-3742. doi:10.1021/acs.orglett.7b01566

16. Liu, Y.; Hu, H.; Wang, X.; Zhi, S.; Kan, Y.; Wang, C. J. Org. Chem. 2017, 82, 4194-4202. doi:10.1021/acs.joc.7b00180

17. Wang, H.; Regan, C. J.; Codelli, J. A.; Romanato, P.; Puchlopek-Dermenci, A. L. A.; Reisman, S. E. Org. Lett. 2017, 19, 1698-1701. doi:10.1021/acs.orglett.7b00418

18. Dong, Z.; Zhu, Y.; Li, B.; Wang, C.; Yan, W.; Wang, K.; Wang, R. J. Org. Chem. 2017, 82, 3482-3490. doi:10.1021/acs.joc.6b02949

19. Motornov, V. A.; Tabolin, A. A.; Nelyubina, Y. V.; Nenajdenko, V. G.; loffe, S. L. Org. Biomol. Chem. 2019, 17, 1442-1454. doi:10.1039/c8ob03126f
20. Zhang, D.; Lin, L.; Yang, J.; Liu, X.; Feng, X. Angew. Chem., Int. Ed. 2018, 57, 12323-12327. doi:10.1002/anie.201806630

21. Day, J.; McKeever-Abbas, B.; Dowden, J. Angew. Chem., Int. Ed. 2016, 55, 5809-5813. doi:10.1002/anie.201511047

22. Brioche, J.; Meyer, C.; Cossy, J. Org. Lett. 2015, 17, 2800-2803. doi:10.1021/acs.orglett.5b01205

23. Allgäuer, D. S.; Mayr, H. Eur. J. Org. Chem. 2013, 6379-6388. doi:10.1002/ejoc.201300784

24. Kucukdisli, M.; Opatz, T. Eur. J. Org. Chem. 2012, 4555-4564. doi:10.1002/ejoc.201200424

25. Jacobs, J.; Van Hende, E.; Claessens, S.; De Kimpe, N. Curr. Org. Chem. 2011, 15, 1340-1362. doi:10.2174/138527211795378209

26. Tsuge, O.; Kanemasa, S.; Takenaka, S. Bull. Chem. Soc. Jpn. 1985, 58, 3137-3157. doi:10.1246/bcsj.58.3137

27. Tsuge, O.; Kanemasa, S.; Takenaka, S. Bull. Chem. Soc. Jpn. 1985, 58, 3320-3336. doi:10.1246/bcsj.58.3320

28. An, J.; Yang, Q.-Q.; Wang, Q.; Xiao, W.-J. Tetrahedron Lett. 2013, 54, 3834-3837. doi:10.1016/j.tetlet.2013.05.053

29. Fernández, N.; Carrillo, L.; Vicario, J. L.; Badía, D.; Reyes, E. Chem. Commun. 2011, 47, 12313. doi:10.1039/c1cc15671c

30. Han, Y.; Hou, H.; Fu, Q.; Yan, C.-G. Tetrahedron 2011, 67, 2313-2322. doi:10.1016/j.tet.2011.01.046

31. Dumitrascu, F.; Caira, M. R.; Georgescu, E.; Georgescu, F.; Draghici, C.; Popa, M. M. Heteroat. Chem. 2011, 22, 723-729. doi:10.1002/hc.20740

32. Grigg, R.; Heaney, F. J. Chem. Soc., Perkin Trans. 1 1989, 198. doi:10.1039/p19890000198

33. Nicolescu, A.; Deleanu, C.; Georgescu, E.; Georgescu, F.; Iurascu, A.-M.; Shova, S.; Filip, P. Tetrahedron Lett. 2013, 54, 1486-1488. doi:10.1016/j.tetlet.2013.01.036

34. Caira, M. R.; Dumitrascu, F.; Georgescu, E.; Georgescu, F.; Popa, M. M. Rev. Roum. Chim. 2011, 56, 771.

35. Jones, R. C. F.; Rafiq, S.; Elsegood, M. R. J.; McKee, V.; Slater, M. J. Chem. - Asian J. 2010, 5, 461-465. doi:10.1002/asia.200900547

36. Hazra, A.; Mondal, S.; Maity, A.; Naskar, S.; Saha, P.; Paira, R.; Sahu, K. B.; Paira, P.; Ghosh, S.; Sinha, C.; Samanta, A.; Banerjee, S.; Mondal, N. B. Eur. J. Med. Chem. 2011, 46, 2132-2140. doi:10.1016/j.ejmech.2011.02.066

37. Cappelli, A.; Giuliani, G.; Anzini, M.; Riitano, D.; Giorgi, G.; Vomero, S. Bioorg. Med. Chem. 2008, 16, 6850-6859. doi:10.1016/j.bmc.2008.05.067

38. Jones, D. T.; Harris, A. L. Mol. Cancer Ther. 2006, 5, 2193-2202. doi:10.1158/1535-7163.mct-05-0443

39. Gomha, S. M.; Dawood, K. M. J. Chem. Res. 2014, 38, 515-519. doi:10.3184/174751914x14067338307126

40. Liu, J.; Yan, P.; Li, Y.; Zhou, Z.; Ye, W.; Yao, J.; Wang, C. Monatsh. Chem. 2014, 145, 617-625. doi:10.1007/s00706-013-1120-6

41. Allgäuer, D. S.; Mayer, P.; Mayr, H. J. Am. Chem. Soc. 2013, 135 , 15216-15224. doi:10.1021/ja407885h

42. Wu, L.; Sun, J.; Yan, C.-G. Org. Biomol. Chem. 2012, 10, 9452. doi:10.1039/c2ob26849c

43. Liu, Y.; Zhang, Y.; Shen, Y.-M.; Hu, H.-W.; Xu, J.-H. Org. Biomol. Chem. 2010, 8, 2449. doi:10.1039/c000277a

44. Georgescu, E.; Dumitrascu, F.; Georgescu, F.; Draghici, C.; Popa, M. M. Rev. Roum. Chim. 2010, 55, 217-221.

45. Georgescu, E.; Georgescu, F.; Draghici, C.; Caproiu, M. T.; Dumitrascu, F. Rev. Roum. Chim. 2010, 55, 1027-1031.

46. Dawood, K. M.; Ragab, E. A.; Khedr, N. A. J. Chin. Chem. Soc. 2009, 56, 1180-1185. doi:10.1002/jccs.200900170 
47. Dawood, K. M.; Ragab, E. A.; Mohamed, S. N.

Z. Naturforsch., B: J. Chem. Sci. 2009, 64, 434-438.

doi:10.1515/znb-2009-0413

48. Caira, M. R.; Georgescu, E.; Georgescu, F.; Popa, M. M.; Dumitraşcu, F. ARKIVOC 2009, No. xii, 242-253.

doi:10.3998/ark.5550190.0010.c21

49. Shestopalov, A. M.; Chunikhin, K. S.; Rodinovskaya, L. A. Chem. Heterocycl. Compd. 2002, 38, 310-313.

doi:10.1023/a:1015687320793

50. Danac, R.; Al Matarneh, C. M.; Shova, S.; Daniloaia, T.; Balan, M.; Mangalagiu, I. I. Bioorg. Med. Chem. 2015, 23, 2318-2327. doi:10.1016/j.bmc.2015.03.077

51. Singh, D.; Sinha, P.; Bansal, R. K. Curr. Green Chem. 2014, 1, 227-231. doi:10.2174/2213346101666140210194354

52. Paira, R.; Mondal, S.; Chowdhury, A.; Banerjee, M.; Maity, A.; Hazra, A.; Mondal, N. B. Tetrahedron Lett. 2013, 54, 3046-3050. doi:10.1016/j.tetlet.2013.03.095

53. Pospíšil, J.; Trávníček, M.; Potáček, M. ARKIVOC 2001, No. ii, 146-162. doi:10.3998/ark.5550190.0002.217

54. Matusiak, G.; Śliwa, W. Monatsh. Chem. 1993, 124, 161-165. doi:10.1007/bf00808675

55. Sun, J.; Zhang, Y.; Shen, G.-L.; Yan, C.-G. ChemistrySelect 2017, 2, 10835-10839. doi:10.1002/slct.201702161

56. Chen, R.; Zhao, Y.; Sun, H.; Shao, Y.; Xu, Y.; Ma, M.; Ma, L.; Wan, X. J. Org. Chem. 2017, 82, 9291-9304. doi:10.1021/acs.joc.7b01042

57. Glushchenko, T. P.; Aksenov, A. V.; Goncharov, V. I. Chem. Heterocycl. Compd. 2009, 45, 351-356. doi:10.1007/s10593-009-0267-x

58. Liu, Y.; Hu, H.-Y.; Liu, Q.-J.; Hu, H.-W.; Xu, J.-H. Tetrahedron 2007, 63, 2024-2033. doi:10.1016/j.tet.2006.12.050

59. Serov, A. B.; Kartsev, V. G.; Aleksandrov, Y. A.; Dolgushin, F. M. Russ. Chem. Bull. 2005, 54, 2432-2436. doi:10.1007/s11172-006-0133-2

\section{License and Terms}

This is an Open Access article under the terms of the Creative Commons Attribution License (http://creativecommons.org/licenses/by/4.0). Please note that the reuse, redistribution and reproduction in particular requires that the authors and source are credited.

The license is subject to the Beilstein Journal of Organic Chemistry terms and conditions:

(https://www.beilstein-journals.org/bjoc)

The definitive version of this article is the electronic one which can be found at: $\underline{\text { doi:10.3762/bjoc. } 15.149}$ 